\title{
Family Perception of Diseases Related to the Reference Time in
} Stroke Patient: Literature Review

\author{
Zelin Resiana Putri*, Bagus Rahmat Santoso \\ Nursing Program, Health Faculty, Universitas Sari Mulia, Indonesia \\ Corresponding author: zelinresiana30@gmail.com
}

\begin{abstract}
Background: Stroke is a functional brain disorder characterized by neurological deficits or nerve paralysis that occurs suddenly due to obstruction of blood flow to the brain. In 2018 the prevalence of stroke in Indonesia has increased compared to 2013, namely the prevalence of stroke rose from 7 percent to 10.9 percent. South Kalimantan ranks 5 th in Indonesia with a stroke prevalence of $12.7 \%$. The duration of stroke is caused by the delays in referring patients to the hospital. Poor perception is one of the factors that causes delay in patients being taken to the hospital for immediate treatment.

Purpose: This study aimed to learn about family perceptions of diseases related to patient referral in Empirical studies in the past 5 years.

Methods: This study uses the literature review method. a database with the electronic search on Ebsco, ProQuest, Google Scholar, and DOAJ that published in 2016-2019.

Results: There is a correlation between the perception of the disease with referral time in stroke patients. Lack of knowledge about the symptoms of stroke symptoms that arise so that the perception of symptoms that arise is an ordinary disease and can disappear by itself. Conclusion: Closely Banjar culture causes families to choose to only bring patients to traditional medicine rather than bringing stroke patients to the hospital. The family has the perception that stroke is a common disease that can be cured by bringing patients to traditional medicine.
\end{abstract}

Keywords: Perception, Referral Time, Stroke. 
Journal Of Nursing Practice

http://thejnp.org

ISSN: 2614-3488 (print); 2614-3496 (online)

Vol.4 No.1. October 2020. Page.107-116

\section{BACKGROUND}

Stroke is a functional brain disorder characterized by neurological deficits or nerve paralysis that occurs suddenly as a result of obstruction of blood flow to the brain. The cause of obstruction of blood flow to the brain can occur due to blockage (ischemic) or bleeding (hemorrhagic) (Junaidi, 2012; Pinzon, 2010). Stroke is characterized by neurological deficits caused by acute central nervous system (CNS) focal injury, including cerebral infarction, intracerebral hemorrhage (ICH), and subarachnoid hemorrhage (SAH), and is a leading cause of disability and death worldwide. Stroke is divided into two types, namely hemorrhagic stroke and non-hemorrhagic stroke. Hemorrhagic stroke is a stroke that occurs due to the rupture of a blood vessel in the brain, while non-hemorrhagic stroke occurs due to blockage of blood vessels to the brain (Sacco, 2013).

The GBD (Global Burden of Disease) study in 2013 identified a significant difference in men and women who suffered from a stroke. Men have a greater incidence of stroke than women (133/100,000 person-years and 99/100,000 person-years) (Feigin, 2017). Stroke accounted for about $11.8 \%$ of total deaths in the world in 2015, and makes stroke number 2 after heart disease as the cause of death in the world (Benjamin, 2018). Stroke is the leading cause of death worldwide (Hata, 2013).

The prevalence of stroke in the United States in adults is around $2.7 \%$, the lowest prevalence in Minnesota is around 1.9\% in adults and the highest prevalence in Alabama is around $4.3 \%$ in adults. The global prevalence of ischemic stroke is 67.6 million and hemorrhagic stroke is 15.3 million. Globally, there was an increase in ischemic strokes of about $2.7 \%$ from 2006 to 2016 and decreased by $0.1 \%$ from 1990 to 2016 . Hemorrhagic strokes decreased by 1.7\% from 2006 to 2016 (Donnino, 2016). Stroke is more than $60 \%$ of the world's population, and many occur in developing countries. Death in Asia due to stroke is higher than in America, Western Europe, or Australia (Venketasubramanian, 2017). Compared with hemorrhagic stroke, ischemic stroke has a higher incidence rate in all countries. The incidence of stroke in Asia ranges from 201 to 483 per 100,000 / year (Tan, 2015).

The results of the 2018 Riskesdas showed the prevalence of stroke in Indonesia had increased compared to the 2013 Riskesdas, namely the prevalence of stroke increased from 7 percent to 10.9 percent (Riskesdas, 2018). South Kalimantan ranks 5th in Indonesia with a stroke prevalence of $12.7 \%$. The prevalence of stroke based on gender, namely in men is $11 \%$ and in women is $10.9 \%$ (Riskesdas, 2013; Riskesdas, 2018).

South Kalimantan itself, especially in Banjarmasin, according to IGD data at Ulin Banjarmasin Hospital in 2019, the prevalence of stroke from January to October was 983 patients. This data increased from 2017 with an average patient arrival of 98 patients per month (RSUD Ulin, 2019). The number of poor perceptions of stroke has led to the worsening condition of stroke patients which should be treated quickly. Because the poor perception of stroke causes a delay or an increase in the length of referral time for stroke patients, where the time to refer stroke patients from the onset of symptoms to receiving treatment in health services is only 3 hours to 4.5 hours (Donnino, 2016). Stroke symptoms are not easily recognized so that many consider that the symptoms of a stroke are symptoms of common diseases such as migraines and food poisoning (Yoon, 2002).

According to AHA (2016), acute stroke care outside the hospital focuses on the rapid identification and assessment of patients with stroke and rapid transportation (with notification before arrival) to facilities capable of providing acute stroke care. In the journal entitled Family Knowledge Role in Delay in Arrival of Acute Ischemic Stroke Patients in the Emergency Room, it is said that $62.07 \%$ of families have insufficient knowledge about the risks and symptoms of stroke, so that families do not immediately bring patients to health 


\section{Journal Of Nursing Practice}

http://thejnp.org

ISSN: 2614-3488 (print); 2614-3496 (online)

Vol.4 No.1. October 2020. Page.107-116

services capable of providing stroke care. I. In this study, $87.9 \%$ of patients came to the emergency room $>3$ hours after the signs of stroke occurred with an average arrival time of 23 hours 12 minutes (Rachmawati, 2017).

Poor perceptions of stroke affect the time of referral to patients, where patients are taken to a family doctor, stroke patients should be treated by emergency medical services (Fladt, 2019). In Indonesia, especially in the city of Banjarmasin, which is still strong in their belief in mystical things or their habits, they perceive that the disease they suffer is an only common disease because of poor perception and lack of knowledge about the signs of stroke symptoms which is reinforced by the high incidence of stroke in South Kalimantan from 2013 by $9.2 \%$, an increase in 2018 by $12.7 \%$ (Trihono, 2013; Siswanto, 2018). From the results of previous studies, it explains the number of bad perceptions about stroke which is still a problem in various countries with the increasing prevalence of strokes which causes delays or delays in bringing patients to the hospital.

\section{OBJECTIVE}

This Literature review do investigate family perception of diseases related to the reference time in stroke patient.

\section{METHODS}

This study uses the literature review method. The process of collecting literature is carried out by selecting the number of national and international journals or articles. The search process is carried out through indexed based electronics such as Ebsco, ProQuest, Google Scholar, and DOAJ which were published in 2016-2019. The keywords used to search for this article included: "patient stroke prehospital delay, stroke perceptions, influencing factor delay stroke patient".

\section{RESULTS}

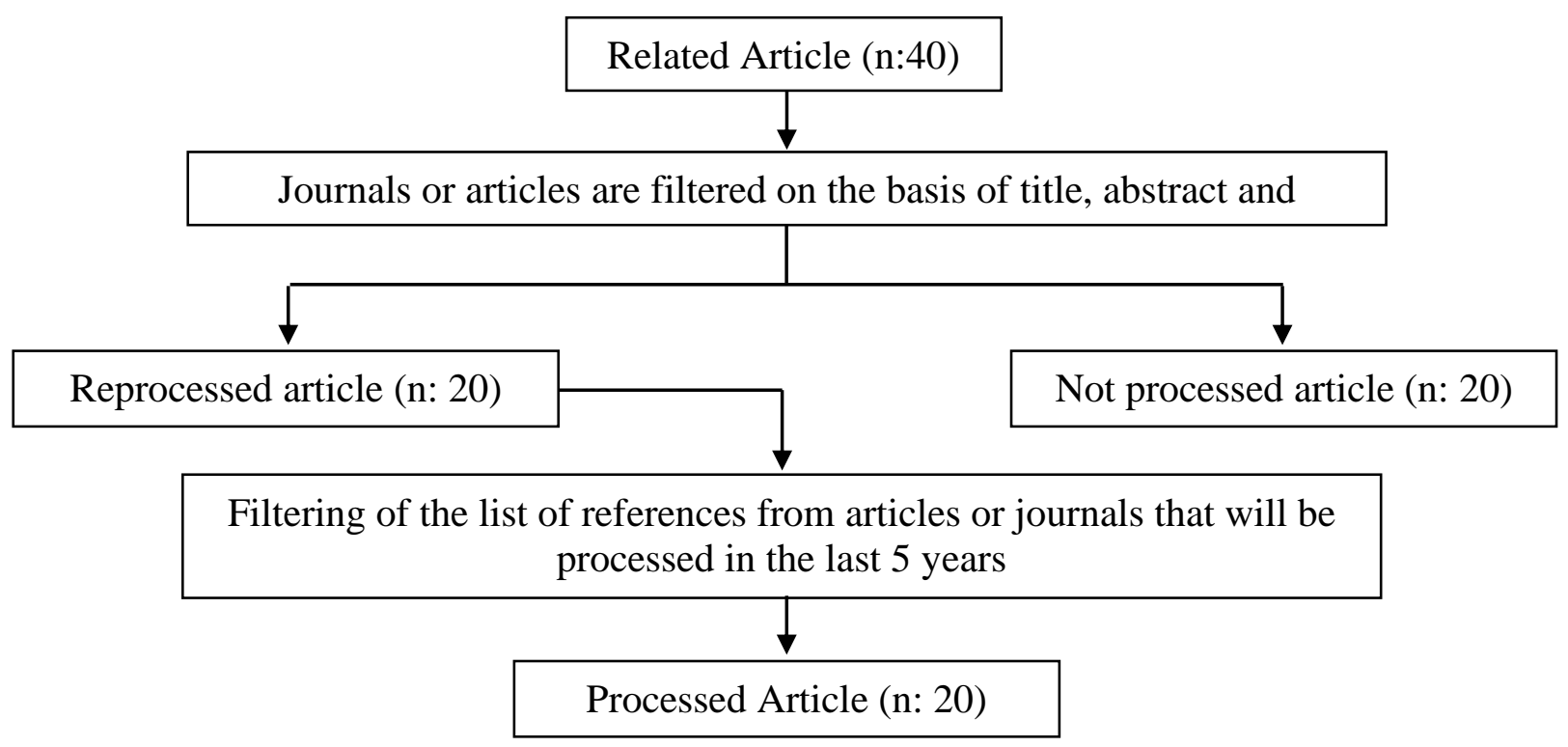

Figure 1. Process literature Review

The stage of the literature review we looked for through Ebsco, ProQuest, Google Scholar, and DOAJ about family perceptions of disease was related to referral time to stroke patients. The obtained journals are as many as 40 journals, after which the journals or articles can be 


\section{Journal Of Nursing Practice}

http://thejnp.org

ISSN: 2614-3488 (print); 2614-3496 (online)

Vol.4 No.1. October 2020. Page.107-116

filtered based on titles, abstracts and keywords. The search results were obtained according to the theme of the literature review obtained 20 journals. The 20 journals were re-screened for the reference list from articles or journals that will be processed in the last 5 years and the relevant results were 10 journals.

Table 1. List of Article Review

\begin{tabular}{|c|c|c|c|c|c|}
\hline $\begin{array}{c}\text { Autor } \\
\text { (Years) }\end{array}$ & $\begin{array}{c}\text { Languag } \\
\mathrm{e}\end{array}$ & $\begin{array}{l}\text { Source } \\
\text { Article }\end{array}$ & Aims & $\begin{array}{l}\text { Research } \\
\text { Method }\end{array}$ & Finding \\
\hline $\begin{array}{l}\text { Camara, } \\
\text { R.S., et al. } \\
2019\end{array}$ & English & DOAJ & $\begin{array}{l}\text { This study aimed to identify } \\
\text { factors associated with PHD } \\
\text { from the onset of acute } \\
\text { stroke symptoms until } \\
\text { arrival at the hospital }\end{array}$ & Deskriptif & $\begin{array}{l}\text { Respondents have the } \\
\text { perception that the signs } \\
\text { of stroke symptoms that } \\
\text { appear are common } \\
\text { diseases and do not need } \\
\text { help to overcome the } \\
\text { disease, because the } \\
\text { perception is that there is } \\
\text { a delay or Pre Hospotal } \\
\text { Delay (PHD). }\end{array}$ \\
\hline
\end{tabular}

\begin{tabular}{|c|c|c|c|c|c|}
\hline $\begin{array}{l}\text { Dolmans, } \\
\text { L.S., et al. } \\
2018\end{array}$ & English & DOAJ & $\begin{array}{l}\text { We aimed to quantify patien } \\
\text { delay and assess its deter- } \\
\text { minants in patients } \\
\text { (suspected of) TIA and } \\
\text { performed a systematic } \\
\text { review. }\end{array}$ & $\begin{array}{l}\text { Systematic } \\
\text { Review }\end{array}$ & $\begin{array}{l}\text { Lack of knowledge } \\
\text { makes relatives only } \\
\text { perceive that the } \\
\text { symptoms of stroke that } \\
\text { appear are common } \\
\text { diseases }\end{array}$ \\
\hline
\end{tabular}

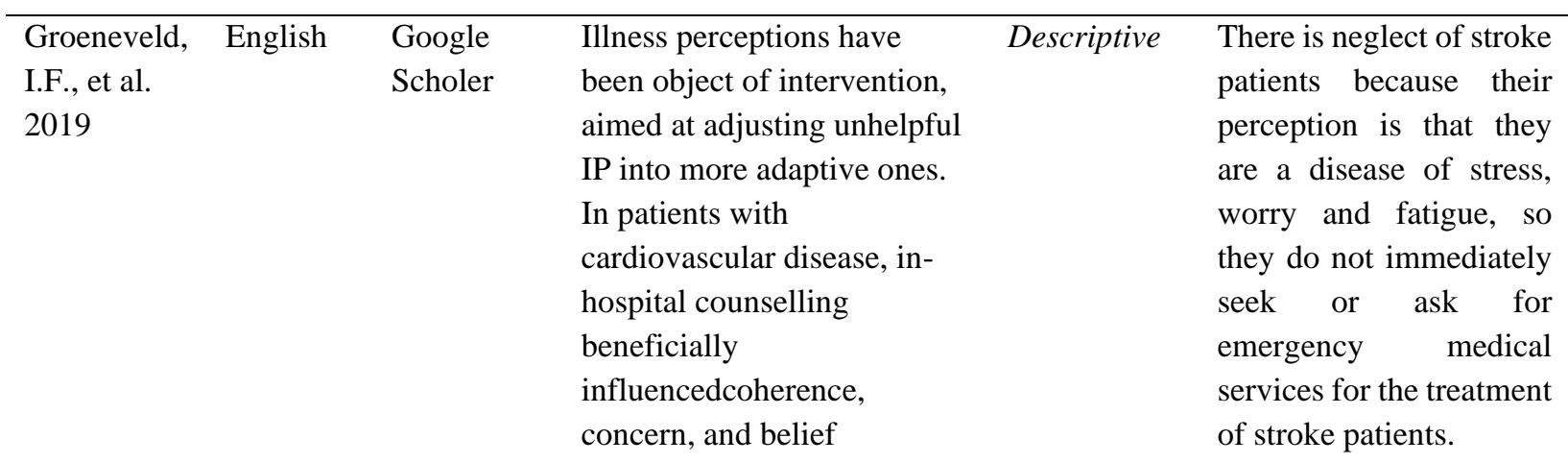

saboutthe causesof disease,

and resulted in fewer

symptoms and a higher rate

of work resumption

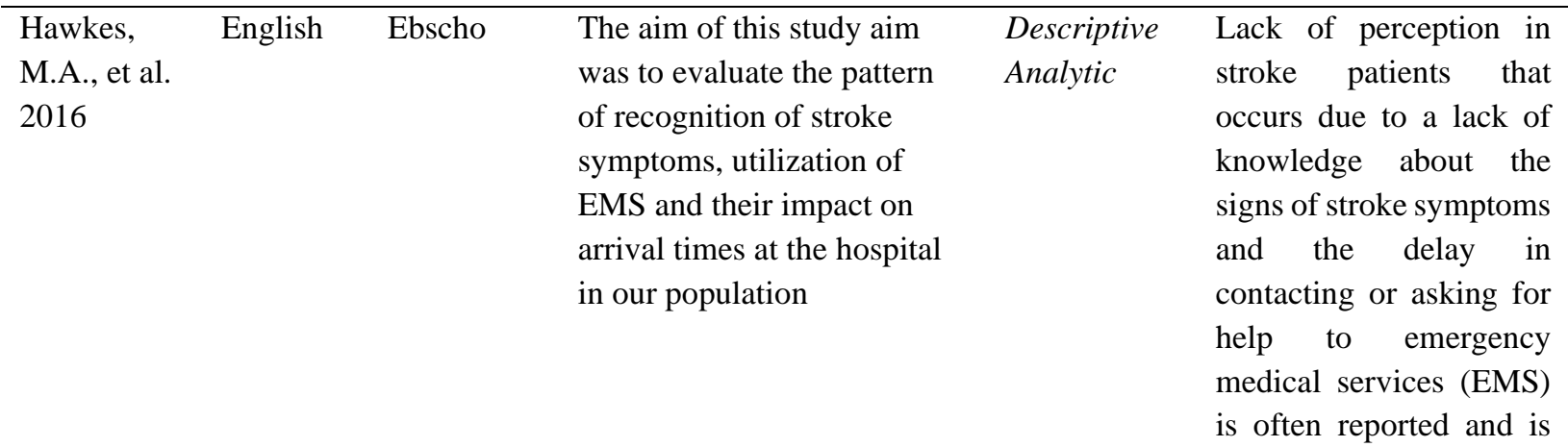




\section{Journal Of Nursing Practice}

http://thejnp.org

ISSN: 2614-3488 (print); 2614-3496 (online)

Vol.4 No.1. October 2020. Page.107-116

the reason for late arrival

to the hospital

\begin{tabular}{|c|c|c|c|c|c|}
\hline $\begin{array}{l}\text { Marinho, } \\
\text { V., et al. } \\
2019\end{array}$ & English & ProQuest & $\begin{array}{l}\text { This review is aimed to } \\
\text { identify the gaps, and } \\
\text { demonstrate a better } \\
\text { understanding of decision- } \\
\text { making and timing functions } \\
\text { in the patients with stroke. } \\
\text { Electronic literature database } \\
\text { was searched and the } \\
\text { findings of relevant studies } \\
\text { were used to explore the } \\
\text { mechanisms of decision- } \\
\text { making and timing in } \\
\text { patients with stroke, as well } \\
\text { as the circuit connections in } \\
\text { timing mediated by } \\
\text { prefrontal cortex and } \\
\text { cerebellum }\end{array}$ & $\begin{array}{l}\text { Literature } \\
\text { Review }\end{array}$ & $\begin{array}{l}\text { The occurrence of } \\
\text { neglect in stroke patients } \\
\text { due to the perception of } \\
\text { relatives who think that } \\
\text { the disease is a common } \\
\text { disease }\end{array}$ \\
\hline $\begin{array}{l}\text { Melnikov S } \\
\text { et al. } 2015\end{array}$ & English & $\begin{array}{l}\text { Google } \\
\text { Scholer }\end{array}$ & $\begin{array}{l}\text { The aim of the current study } \\
\text { was to examine stroke } \\
\text { awareness and knowledge } \\
\text { among new immigrants from } \\
\text { the Former Soviet Union } \\
\text { (IFSUs) compared with } \\
\text { veteran residents (VRs) }\end{array}$ & Descriptive & $\begin{array}{l}\text { The long time to refer to } \\
\text { stroke patients is due to } \\
\text { self-efficacy, which is a } \\
\text { bad perception that } \\
\text { influences behavior to } \\
\text { seek help and causes a } \\
\text { lack of awareness that } \\
\text { stroke patients need to be } \\
\text { treated immediately by } \\
\text { emergency medical } \\
\text { services, which causes } \\
\text { delays in patient arrival } \\
\text { at the hospital. }\end{array}$ \\
\hline
\end{tabular}

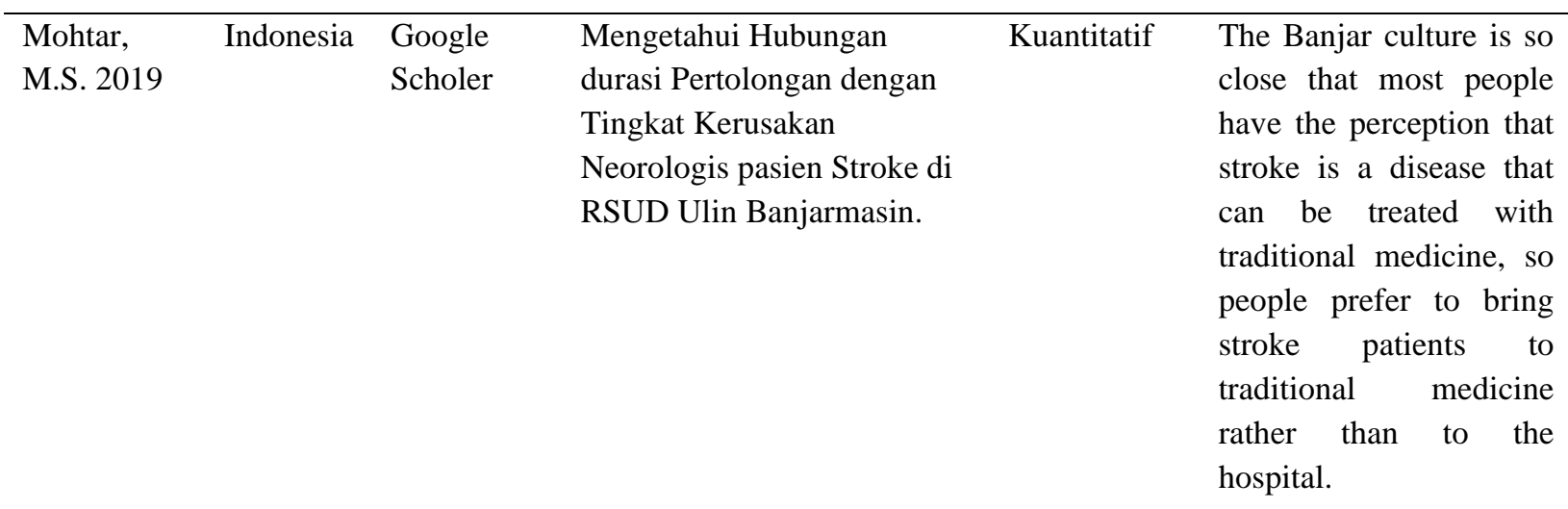

\begin{tabular}{|c|c|c|c|c|c|}
\hline $\begin{array}{l}\text { Rahmina, } \\
\text { Y., et al. } \\
2017\end{array}$ & Indonesia & $\begin{array}{l}\text { Google } \\
\text { Scholer }\end{array}$ & $\begin{array}{l}\text { Tujuan dari Penelitian ini } \\
\text { adalah untuk mengetahui } \\
\text { hubungan tingkat pendidikan } \\
\text { terhadap golden hour pasien }\end{array}$ & $\begin{array}{l}\text { Deskriptif } \\
\text { Analitik }\end{array}$ & $\begin{array}{l}\text { Perception is one of the } \\
\text { factors that influence the } \\
\text { delay in the golden hour } \\
\text { stroke }\end{array}$ \\
\hline
\end{tabular}




\section{Journal Of Nursing Practice}

http://thejnp.org

ISSN: 2614-3488 (print); 2614-3496 (online)

Vol.4 No.1. October 2020. Page.107-116

stroke di RSUD Ulin

Banjarmasin

\begin{tabular}{|c|c|c|c|c|c|}
\hline $\begin{array}{l}\text { Ruiz, R.G., } \\
\text { et al. } 2017\end{array}$ & Inggirs & DOAJ & $\begin{array}{l}\text { Previous studies have } \\
\text { focused on prehospital or } \\
\text { decision delay. We aim to } \\
\text { give a more comprehensive } \\
\text { view by addressing dif- } \\
\text { ferent time delays and } \\
\text { decisions. }\end{array}$ & Deskriptif & $\begin{array}{l}\text { Poor perceptions of } \\
\text { stroke are caused by a } \\
\text { lack of knowledge about } \\
\text { the signs of symptoms, } \\
\text { thus affecting families in } \\
\text { making decisions about } \\
\text { contacting emergency } \\
\text { medical services }\end{array}$ \\
\hline $\begin{array}{l}\text { Wolters, } \\
\text { F.J., et al. } \\
2018\end{array}$ & English & PubMed & $\begin{array}{l}\text { To determine the association } \\
\text { of public education } \\
\text { associations with delays and } \\
\text { failures in seeking medical } \\
\text { attention after TIA and mild } \\
\text { stroke. }\end{array}$ & $\begin{array}{l}\text { Descriptive } \\
\text { Analytic }\end{array}$ & $\begin{array}{l}\text { There is a delay or delay } \\
\text { in stroke patients in } \\
\text { seeking help because the } \\
\text { perception that arises is } \\
\text { an ordinary disease that } \\
\text { can heal itself with just } \\
\text { rest }\end{array}$ \\
\hline
\end{tabular}

\section{DISCUSSION}

The results of the literature study that I found that several factors influence the delay in golden hour of stroke patients, namely knowledge, education level, perception, transportation and economy (Rahmina, 2017). One of the factors causing the delay in referring stroke patients is perception. According to Fadlillah (2018), perception is a process of observing a person about the environment of the act of compiling, recognizing, and interpreting information using his senses to produce a response or description of the environment (Fadlillah, 2018).

The reason why there is a delay or delay in stroke patients in seeking help is because they think that the symptoms that arise are just ordinary diseases, they wait for these symptoms to heal by themselves only by resting. This poor perception occurs due to a lack of knowledge about the signs of stroke symptoms. Some studies say that patients come more than 24 hours after the onset of stroke symptoms to the hospital because of a lack of knowledge about stroke symptoms so that relatives or family do not recognize the symptoms that arise and the family does not contact emergency medical services or take patients to the emergency room (Wolters, 2018).

This lack of knowledge causes the family's inability to recognize stroke symptoms, misinterpretation of visible symptoms so that they think that existing symptoms are not serious and can disappear by themselves so they do not immediately contact emergency medical services or take them to the emergency room (Rachmawati, 2017).

Education is an effort to change a person's behavior, including health behavior to prevent stroke. As in the family education function, a person must be able to show behavior following with his / her role and duties so that they can make the right decisions to choose appropriate health care and maintenance. Besides, education can change the perception of people who initially choose to bring stroke patients to traditional medicine which causes delays in handling or stabbing stroke patients, so they leave the golden hour that should be (Rahmina, 2017). 


\section{Journal Of Nursing Practice}

http://thejnp.org

ISSN: 2614-3488 (print); 2614-3496 (online)

Vol.4 No.1. October 2020. Page.107-116

In a study conducted by Hawkes (2016), the study stated that the lack of perception in stroke patients that occurs due to a lack of knowledge about the signs of stroke symptoms and the delay in contacting or asking for help to emergency medical services (EMS) is often reported and is the reason for late arrival. to the hospital. Seventy patients (75\%) arrived at the hospital more than 4.5 hours after stroke symptoms appeared. Most of the patients who recognize the symptoms do not immediately contact EMS (emergency medical services) or emergency medical services, nineteen patients $(20 \%)$ initially mistakenly think that the symptoms that appear are a stroke (Hawkes, 2016).

The perception of the signs of stroke symptoms which are considered to be common diseases so that the thought that they can control the symptoms without any help causes the Pre Hospital Delay (PHD). Besides, the symptoms of stroke affect the patient's ability to seek help, therefore, the delay in PHD is longer (Camara, 2019). Lower perceptions of the disease and less knowledge of paresis (impaired movement of the body or impaired movement) and aphasia (impaired communication), which are symptoms of stroke, can prolong the referral time in stroke patients. The main limitation of stroke symptoms is FAST (Face, Arm, Speech, Time), which are some of the symptoms of stroke that are often ignored, causing delays in the handling of stroke patients. Besides that, what is more important is the lack of data about the knowledge of patients or witnesses about stroke and their poor perception at the onset of the stroke. However, the information received by patients and families about the actual diagnosis and choice of treatment can influence the decisions they will take (Ruiz, 2017).

Acute stroke care is underutilized mainly due to late arrival at the hospital. Selfefficacy or self-efficacy is a person's perception of himself or his abilities and this perception often affects behavior rather than actual ability. Self-efficacy is an important component of behavioral acute and chronic health. For example, self-efficacy has been associated with a greater intention to seek emergency care in stroke patients, but this lack of good perception has led to a lack of awareness that stroke patients need to be treated immediately by emergency medical services, leading to late arrival of patients at the hospital (Melnikov, 2016).

In a study conducted by Marinho (2019), many of the patient's relatives ignore the symptoms experienced by stroke patients. The poor perception of stroke symptoms results in neglect of stroke patients and causes a long time to make decisions (Marinho, 2019). They have the perception that stroke is a disease of stress, worry and fatigue, so they do not immediately seek or ask for emergency medical services for the treatment of stroke patients. They consider that the symptoms of a stroke that arise are an ordinary disease so they only wait until the symptoms heal by themselves (Groeneveld, 2019).

Perception is one of the factors that influence the family delay in bringing stroke patients to the hospital. The close culture of the banjar is still believed by most people in the treatment of stroke. The public perception of choosing stroke treatment is taking patients to traditional medicine compared to taking the patient to the hospital or immediately calling emergency medical services. The public perception is not accurate because of ignorance about the golden hour stroke. Delays in handling stroke can result in permanent disability or death. (Mohtar, 2019).

The perception that arises only considers an ordinary illness so they often ignore the symptoms of stroke that arise. Poor perception is due to a lack of knowledge about the signs of stroke symptoms, causing delays in patients who should be treated immediately. Campaigns like Face Arm Speech Time (FAST) that educate on recognizing stroke symptoms are important examples of initiatives to gain time. Some of the data on the impact of the FAST campaign suggest a positive effect on awareness of stroke symptoms. However, 


\section{Journal Of Nursing Practice}

http://thejnp.org

ISSN: 2614-3488 (print); 2614-3496 (online)

Vol.4 No.1. October 2020. Page.107-116

the effect on patient response is limited, and it is therefore emphasized that future campaigns should strengthen response to stroke symptoms; the need to respond promptly and contact a health care professional. Lay people need to be better informed about the risk of early stroke and the need for emergency calls after TIA, also when symptoms are brief (Dolmans, 2019).

Success in stroke management is very dependent on speed, accuracy and accuracy in the initial handling of stroke. The golden window or golden window in stroke management is \pm 3 hours, which means that within 3 hours of the initial stroke, the patient must immediately receive comprehensive and optimal therapy from the hospital emergency team to get optimal treatment results. The case that most often occurs in Indonesia in terms of handling stroke patients to the hospital since the start of a stroke is the delay in handling stroke patients. Proper handling at the onset of a stroke can reduce the disability rate by $30 \%$ (Barahama, 2019)

Success in pre-hospital handling of stroke patients' families is influenced by the level of family knowledge in detecting a stroke, the family can identify risk factors for stroke, the distance from the location of the stroke to health services, family assistance as a support system, previous stroke history, stroke comorbidities. associated with stroke severity, and economic factors in the cost of care. There are still many community members who do not know the signs and symptoms of stroke that appear, which is a major problem in delays in management after a stroke. The American Stroke Association developed a series of focus on stroke recognition and activation of EMS (Emergency Medical Service) or emergency medical services through Detection, Dispatch, Delivery for pre-hospital, Data, Decision, Drug while in hospital. (Sari, 2019; Setianingsih, 2019).

There are several risk factors for stroke that can be divided into two categories, namely risk factors that cannot be changed and those that can be changed. Risk factors that cannot be changed include age, gender, according to genetics, while the risk factors that cannot be changed are physical activity, hypertension, smoking, diabetes, consumption of alcoholic beverages and drug abuse (Alchuriyah, 2016; Feigin 2017; Kesuma , 2019).

The community does not only need health education, the community also needs a tool to assess the early symptoms of stroke (detection) which can also be validated by medical personnel. According to the American Heart Association, one tool that is easy to understand and quickly applied is the F.A.S.T. (Face drooping, Arm Weakness, Speech difficulty, Time to call 911). The initial assessment focuses on asymmetry of the face, weakness in the extremities and difficulty speaking (Barahama, 2019; Sari, 2019; Setianingsih, 2019).

\section{CONCLUSION}

There are still many people who have the perception that stroke symptoms are an ordinary disease that can disappear by itself by resting or just being taken to traditional medicine. Bad perceptions cause delays in referring patients to the hospital, so that it can increase the incidence of disability and death in stroke patients because the worsening condition of stroke patients is too late to be treated immediately. The impact of late handling of stroke patients more than the golden hour (3-4.5 hours) can cause cognitive impairment to permanent disabilities. So that handling stroke patients needs to be handled properly and as quickly as possible to reduce the number of physical disabilities due to stroke The need to improve people's perceptions of stroke by providing an initial understanding of prehospital, such as signs of stroke symptoms and where to ask for help by doing health education to the public by medical personel. 


\section{Journal Of Nursing Practice}

http://thejnp.org

ISSN: 2614-3488 (print); 2614-3496 (online)

Vol.4 No.1. October 2020. Page.107-116

\section{REFERENCES}

Alchuriyah, S., Wahjuni, C.U. (2016). The Factor That Affect Stroke at Young Age In Brawijaya Hospital Surabaya. Jurnal Berkala Epidemiologi, 4(1), 62-73.

Barahama, D.V., Tangkudung, G., Kembuan, M.A.H. (2019). Faktor-Faktor Yang Berhubungan Dengan Keterlambatan kedatangan pasien Stroke di RSUP Prof. Dr. R. D. Kandou Manado. Jurnal E-Clinic (ECL), 7(1), 1-6.

Benjamin, E.J., Virani, S.S., Callaway, C.W., et al. (2018). Heart Disease and Stroke Statistics 2018 Update. Heart Disease and Stroke Statistics, 137(12). https://www.ahajournals. org/doi/10.1161/CIR.00 00000000000558

Camara, R.C., Santos, J.G., Bernal, J.G., Santidrian, A.M., Cubo, E., \& Trejo-GabrielGalán, J. M. (2019). Factors Associated with Shortening of Prehospital Delay among Patients with Acute Ischemic Stroke. Journal of clinical medicine, 8(10). 1712. https://doi.org/10.3390/jcm8101712

Dolmans, L.S., Hoes, A.W., Bartelink, M.E.L. (2019). Patient Delay in TIA: A Systematic Review. Journal of Neurology, 266(1), 1051-1058. https://doi.org/10.1007/s00415018-8977-6

Donnino M.W, Navarro K, Berg K. 2016. Advanced Cardiovaskular Life Support. United States Of America: American Heart Association.

Fadlillah, M. (2018). Persepsi Mahasiswa PG-PAUD Universitas Muhammadiyah Ponorogo terhadap PAUD di Kabupaten Ponorogo. Jurnal Obsesi, 2(1), 118123. https://doi.org/10.31004/obsesi.v2i1.15

Groeneveld, I. F., Van der Pas, S. L., Meesters, J. J. L., Schuurman, J. M., van MeijerenPont, W., Jagersma, E., Vlieland, T. P. M. (2019). Illness perceptions of stroke survivors: Predictors and changes over time A 1 year follow-up study. Journal of Psychosomatic Research, 116(1), 54-61. Tersedia pada: DOI:10.1016/j.jpsychores.2018.10.019

Hata J, Kiyohara Y. 2013. Epidemiology of Stroke and Coronary Artery Disease in Asia . Cardiovascular Epidemiology In Asia, 77(2): 1923-1924. DOI: 10.1253/circj.cj-130786

Hawkes, M. A., Farez, M. F., Calandri, I. L., \& Ameriso, S. F. (2016). Perception Of Stroke Symptoms And Utilization Of Emergency Medical Services. Arquivos de Neuro-Psiquiatria, 74(11), 869-874. DOI: 10.1590/0004-282x20160142

Junaidi, I. (2011). Stroke Waspadai Ancamannya. Yogyakarta: C.V Andi Offset.

Kemenkes. (2013). Pokok-pokok Hasil Riskesdas. Indonesia: Kementerian Kesehatan Republik Indonesia. http://kesga.kemkes.go. id/images/pedoman/Data\%20Riskesdas\%202013.pdf

Kemenkes. (2018). Laporan Nasional RISKESDAS. Indonesia: Kementerian Kesehatan Republik Indonesia. http://www.kesmas. kemkes.go.id/assets/upload/dir_519d41d8cd98f00/files/Hasil-riskesdas2018 1274.pdf

Marinho, V., Pinto, G. R., Bandeira, J., Oliveira, T., Carvalho, V., Rocha, K., Magalhaes, F., Sousa, V. G., Bastos, V. H., Gupta, D., Orsini, M., \& Teixeira, S. (2019). Impaired decision-making and time perception in individuals with stroke: Behavioral and neural correlates. Revue neurologique, 175(6), 367-376. https://doi.org/10.1016/j.neurol.2018.10.004

Melnikov, S., Itzhaki, M., \& Koton, S. (2016). Differences Between New Immigrants From the Former Soviet Union and Veteran Residents in Knowledge, Perception, and Risk Factors of Stroke. The Journal of Cardiovascular Nursing, 31(6), 500 506. DOI: $10.1097 / \mathrm{jcn} .0000000000000278$ 


\section{Journal Of Nursing Practice}

http://thejnp.org

ISSN: 2614-3488 (print); 2614-3496 (online)

Vol.4 No.1. October 2020. Page.107-116

Mohtar, M.S. (2019). Hubungan Durasi Pertolongan Dengan Tingkat Kerusakan Neorologis Pasien Stroke di RSUD Ulin Banjarmasin . Dinamika Kesehatan Jurnal Kebidanan dan Keperawatan , 10(1), 224-238.Tersedia pada: DOI: https://doi.org/10.33859/dksm.v10i1.331

Nasution, M.I. (2019). Patient Safety Sebagai Pencegahan KTD Dan Peningkatan Kualitas Pelayanan Rumah Sakit. OSFPREPRINT. DOI: https://doi.org/10.31219/osf.io/89kns

Pinzon, R., \& Asanti, L. (2010). Awas Stroke. Yogyakarta: CV. Andi Offset.

Rachmawati D, Andarini S, Ningsih D.K. 2017. Pengetahuan Keluarga Berperan terhadap Keterlambatan Kedatangan Pasien Stroke Iskemik Akut di Instalasi Gawat Darurat. Jurnal Kedokteran Brawijaya, 29(4): 369-376. http://dx.doi.org/10.21776/ ub.jkb.2017.029.04.15

Rahmina., Wahid A., Agustina, R. (2017). Tingkat Pendidikan Keluarga Terhadap Golden Hour Pasien Stroke di RSUD Ulin Banjarmasin. Jurnal Keperwatan dan Kesehatan, 5(1), 68-77. DOI: http://dx.doi.org/10.20527/dk.v5i1.3644

RSUD Ulin. 2019. Data Kunjungan Pasien Stroke di IGD RSUD Ulin Banjarmasin Dari Bulan Januari Sampai Bulan Oktober. Banjarmasin: RSUD Ulin.

Ruiz, G.R., Fernandez, S.J., Ruiz, R.M., Bermejo, M.R., Arias, A.Á., Saucedo, P.D., Aleman, J.A. (2018). Response to Symptoms and Prehospital Delay in Stroke Patients. Is It Time to Reconsider Stroke Awareness Campaigns. Journal of Stroke and Cerebrovascular Diseases, 27(3), 625-632. DOI:

10.1016/j.jstrokecerebrovasdis.2017.09.03

Sacco R.L., Kasner S.E., Broderick J.P., Caplan L.R., Antonio, C. (2013). An Updated Definition of Stroke for the 21st Century. AHA/ASA Expert Consensus Document, 2065-2066. https://www.ahajournals.org/doi/pdf/10.1161/str.0b013e318296aeca

Sari, L.M., Yuliano, A., Almudriki. (2019). Hubungan Pengetahuan Dan Sikap Keluarga Terhadap Kemampuan Deteksi Dini Serangan Stroke Iskemik Akut Pada Penanganan Pre Hopsital. Jurnal Kesehtan perintis, 6(1), 74-81.

DOI: https://doi.org/10.33653/jkp.v6i1.241

Setianingsih., Darwati L.E., Prasetya H.A. (2019). Study Deskriptif Penanganan Prehospital Stroke Life Support Pada Keluarga. Jurnal Perawat Indonesi, 3(1), 55-64. DOI: http://dx.doi.org/10.32584/jpi.v3i1.225

Tan, C.S., Riemenschneider, F.K., Xian, S.H., Tan, P.Z., Bernard, P.L., Tang, K.F., et al. 2015. Trends in Stroke Incidence and 28-Day Case Fatality in a Nationwide Stroke Registry of a Multiethnic Asian Population. Trends in Stroke Incidence and 28-Day Case Fatality, 46(4): 2728-2730. DOI: https://doi.org/10.1161/STROKEAHA. $\underline{115.009797}$

Wilianto \& Kurniawan, A. (2018). Sejarah, Cara Kerja Dan Manfaat Internet Of Things. Jurnnal Matrix, 8(2), 36-41. DOI: http://dx.doi.org/10.31940/matrix.v8i2.818

Wolters, F.J., Li, L., Gutnikov, S.A., Mehta, Z., \& Rothwell, P.M. (2018). Medical Attention Seeking After Transient Ischemic Attack and Minor Stroke Before and After the UK Face, Arm, Speech, Time (FAST) Public Education Campaign: Results From the Oxford Vascular Study. JAMA neurology, 75(10), 1225-1233. DOI: https://doi.org/10.1001/jamaneurol.2018.1603

Yoon S.S, Byles J. 2002. Perceptions Of Stroke In The General Public And Patients With Stroke: A Qualitative Study, 19(3): 1-2. https://doi.org/10.5853/jos.2017.00234 